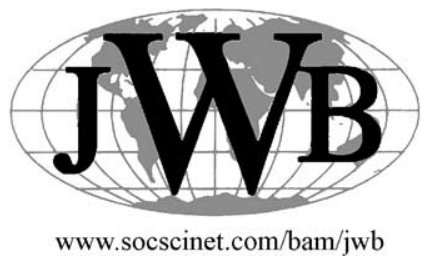

\title{
Understanding venture capital in East Asia: the impact of institutions on the industry today and tomorrow

\author{
Garry Bruton ${ }^{\mathrm{a},{ }^{*}}$, David Ahlstrom ${ }^{\mathrm{b}, 1}$, Kuang S. Yeh ${ }^{\mathrm{c}, \mathrm{d}, 2}$ \\ ${ }^{a}$ Department of Management, M.J. Neeley School of Business, Texas Christian University, P.O. Box 298530, Fort Worth, TX 76129, USA \\ ${ }^{\mathrm{b}}$ Department of Management, The Chinese University of Hong Kong, Shatin, NT, Hong Kong, China \\ ${ }^{\mathrm{c}}$ Pacific Broadband Co., Ltd., Taipei, Taiwan \\ ${ }^{\mathrm{d}}$ Department of Business Management, National Sun Yat-sen University, Kaohsiung, Taiwan
}

Accepted 18 August 2003

\begin{abstract}
Venture capital in East Asia has played a significant economic role in the region's development and is expected to play an even more significant role in the future. However, our understanding of the industry remains very limited. It is known that institutions present in East Asia shape the behavior of organizations that are present in the region. This article examines how institutions, particularly those related to the regulatory environment and culture of East Asia, shape the venture capital industry and create differences from the venture capital industry in the West. These differences are true despite the fact that many venture capitalists have been trained in Western venture capital firms and share similar beliefs about how venture investments are to be made. The article concludes with a research agenda for building a fuller understanding of how venture capital works in East Asia and what outside investors and firms need to familiarize themselves with.
\end{abstract}

(C) 2003 Published by Elsevier Inc.

\section{Introduction}

Venture capital has been widely recognized as having an important function in regional economic development (Sapienza, Manigart, \& Vermeir, 1996; Saxenian, 1994). The vital role it plays has helped to encourage interest in venture capital throughout the world (Gupta, 2000). To date most research on the industry has occurred in the West in spite of the industry's growth in other regions. In Asia, $\$ 7.4$ billion

\footnotetext{
* Corresponding author. Tel.: +1-817-257-7421; fax: +1-817-257-7227.

E-mail addresses: g.bruton@tcu.edu (G. Bruton), ahlstrom@baf.msmail.cuhk.edu.hk (D. Ahlstrom), kuang.yeh@elinx.com.tw (K.S. Yeh).

${ }^{1}$ Tel.: +852-2609-7748.

${ }^{2}$ Tel.: +886-7-525-4652.
}

of new funds were raised in 1998 alone (Guide to Venture Capital in Asia, 2000). Though the funds invested by the venture capital industry play an increasingly important role in the economic vitality of the region (Ang, Lee, Lim, Singh, \& Tan, 2000; Timmons, 1999; Wang \& Sim, 2001), little is known about Asian venture capital in general, and East Asian venture capital in particular (Bruton, Dattani, Fung, Chow, \& Ahlstrom, 1999; Wang \& Sim, 2001).

A central argument in much of the research on global business is that firms are embedded in country-specific institutional arrangements (Busenitz, Gomez, \& Spencer, 2000; Child, 2000). These institutions impact the behavior of both individuals and firms in subtle but pervasive ways (Ang et al., 2000; Peng, 2003; Scott, 1995, 2002). The institutional differences in countries extend beyond basic differences in culture to funda- 
mental elements of a nation's laws, business norms, and commercial traditions (Kostova, 1997; Orru, Biggart, \& Hamilton, 1997; Peng, 2002). Institutions are typically situation specific, thus the institutional characteristics of a country are best examined with regard to a specific phenomenon such as the venture capital industry rather than in terms of general arrangements (Busenitz et al., 2000; Lowe, 1998; Orru et al., 1997).

This article examines the practice of venture capital in East Asia. Of particular interest is how indigenous institutions (Lau, Tse, \& Zhou, 2002; Tsui \& Lau, 2002) affect the venture capital industry and create differences from that of the West. ${ }^{3}$ Attention is focused on venture capital in Hong Kong, Singapore, and Taiwan. These regions represent three key centers of the venture capital industry in East Asia plus the three primary venture capital centers in East Asia dominated by Overseas Chinese. This ethnic group is well known for a number of idiosyncratic business practices that have created a distinctive commercial system (Chen, 2001; Weidenbaum, 1996). These practices and other local institutions shape behavior in that region and could be expected to impact the function of the venture capital industry. The venture capital industry in East Asia is also influenced by normative practices from the West. Thus, this article not only examines current institutional influences on the venture capital industry in East Asia, but also considers the future of the industry in the face of increasing globalization. Finally, a research agenda and implications for managers of this vital domain will be discussed based on these findings.

\section{What is meant by venture capital?}

Venture capital in the West is commonly associated with investments in early stage ventures where investment is made in return for an equity stake in a new business. Firms which make venture investments in later stage or mezzanine ventures or firms that invest in mature companies seeking to turn those enterprises around are not called venture capital firms in the West, rather they are associated with private equity finan-

\footnotetext{
${ }^{3}$ Sapienza et al. (1996) found strong similarities between the U.S. and European venture capital industry and they are considered together here as the Western venture capital industry.
}

cing. However, in East Asia the industry's dividing lines are not as distinct as in the West. Firms commonly do not focus on single types of investments as occurs in the West. Rather they focus on funding firms in narrower geographic regions as the ability to monitor funded firms is much more constrained due to travel and communication limitations (Ahlstrom, Bruton, \& Chan, 2000; Bruton, Ahlstrom, \& Singh, 2002). Thus, the term venture capital predominates in Asia but some of that activity would likely be called private equity in the West.

\subsection{An overview of venture capital in East Asia}

The size of the overall East Asian venture capital industry can be measured a variety of ways. Three of the most common measures are number of venture capital companies, number of professionals in those companies, and capital under management. Table 1 provides summary statistics for the Asian venture capital industry.

The industry in the United States (U.S.) has approximately twice as many firms as in Asia. However, the amount of money in the U.S. industry is much larger. To illustrate, in 1998 the private equity and venture capital industry together raised an estimated $\$ 90$ billion in new capital while the comparable amount in Asia was around $\$ 7$ billion. Overall, the industry in the West, particularly the U.S., is much larger and better established than in Asia. The size of the firms and the funds they raise are larger. The result

Table 1

Overview of Asian venture capital

\begin{tabular}{lccc}
\hline Country & $\begin{array}{l}\text { Number of } \\
\text { companies }\end{array}$ & $\begin{array}{l}\text { Number of } \\
\text { professionals }\end{array}$ & $\begin{array}{l}\text { Capital } \\
\text { (U.S. millions) }\end{array}$ \\
\hline Hong Kong/PRC & 29 & 494 & 15,442 \\
Indonesia & 46 & 189 & 328 \\
Japan & 231 & 1,786 & 12,513 \\
Korea & 123 & 409 & 2,995 \\
Malaysia & 20 & 59 & 460 \\
Singapore & 64 & 331 & 5,258 \\
Taiwan & 124 & 356 & 3,598 \\
Thailand & 8 & 49 & 15 \\
Vietnam & 7 & 28 & 258 \\
Total & 752 & 3,701 & 40,867 \\
\hline
\end{tabular}

Source of data: The 2000 Guide to Venture Capital in Asia, published by The Asian Venture Capital Journal. 
is that venture capital professionals in the West must manage larger funds and typically make larger investments than do their counterparts in East Asia. Additionally, many of the mechanisms that support venture capitalists, such as services needed in conducting due diligence, are better established in the West.

As Table 1 shows, three of the principal centers of venture capital activity in East Asia are Hong Kong, Singapore, and Taiwan. Ethnic Chinese dominate most elements of the economic life of these three geographic areas and have been shown to have strong cultural institutions that impact other business phenomenon (Chen, 2001). Focusing our examination on this particular ethnic group in these three particular locations in a single industry allows for greater control of extraneous variables.

\section{Regional institutions and venture capital}

It has been argued that venture capitalists will follow a similar worldwide model of investing, particularly for later stage ventures (Jeng \& Wells, 2000). This argument is based primarily on research that did not include firms from countries in Asia. However, it is widely recognized that East Asia has an environment and institutions that differ from those of the U.S. and Europe, which in turn can create extensive differences in commercial practice and activity (Boisot \& Child, 1988, 1996; Chen, 2001; Orru et al., 1997; Peng, 2000). Some have summarized those differences under the heading of Confucian dynamism (Hofstede \& Bond, 1988). Whereas in the West, efficiency, profit motive, and responsiveness to investors are thought to rank supreme, in East Asia, building legitimacy, maintaining harmony and securing connections are of key concern to businesspeople (Ahlstrom \& Bruton, 2001; Chen, 2001). In trying to understand the venture capital industry in East Asia a key question is, do venture capitalists follow a Western model of venture capital or do they conform more to the East Asian environment with its numerous customs and differences, and what are the implications for the venture capital industry and the funding of entrepreneurial firms in East Asia?

Institutional theory provides a useful lens through which to examine these questions. Central to institutional theory is the assertion that institutions in the environment have an impact on a range of commercial activity including the actions people take and those that they even consider possible. The institutional aspects that shape organizational activity include regulatory, normative, and cognitive components (Scott, 1995, 2002) and are examined in turn below.

Regulatory elements of institutions represent laws and sanctions that regulate the behavior of firms and individuals (North, 1990). Regulatory processes involve the setting of rules and their enforcement. For example, insider-trading laws persuade individuals and firms to neither take nor tolerate such actions. Thus, regulatory institutions include sanctions, laws, and regulatory fiat that regulate individual and organizational action (Scott, 1995). Financial and commercial rules in East Asia are generally less developed than those of the West, and even when rules are present they are often not as strictly enforced (Backman, 1999; Khanna \& Palepu, 1999). This fact has strong bearing on contracts and corporate governance, key concerns to the venture capitalist (Phan, 2000). The weakness in regulatory institutions can make the selection process of firms to fund more difficult and thus more challenging for East Asian venture capitalists.

Normative elements of institutions define the roles or actions that derive from professional standards and are propagated through teaching and training (DiMaggio, 2001). To illustrate, the medical and accounting professions have developed strong norms of behavior through the education and training process for their respective professions (Freidson, 1986; Mezias, 1990). Similarly, an increasing amount of business activity occurs under the auspices of benchmarking or setting of behavior expectations of a firm by the behavior of leading firms in the industry; such benchmarking efforts help to establish normative institutions in the industry (DiMaggio, 2001). Much of the argument that venture capital in East Asia is converging with the Western model rests on the fact that the venture capital training is the same in East Asia and the West. Many East Asian venture capitalists have either worked for a Western firm where they received their training in the industry or currently are associated with Western venture capital firms in some manner. Those Western firms provide natural benchmarks for the behavior of venture capitalists in East Asia. Thus, the normative practice of venture capital in East Asia is strongly influenced by practices from the West with respect to what venture capitalists should be doing and 
how they should be doing it (Bruton, Manigart, Fried, \& Sapienza, 2001).

Cognitive elements of institutions are most closely associated with culture in that they typically are created and carried by the culture of a given region (Berger \& Lickman, 1967; Jepperson, 1991; Scott, 2002). These institutions typically include informal constraints embodied in traditions including subconsciously accepted rules and customs, and taken-forgranted commercial conventions. These cultural/cognitive institutions develop over time through social interactions among the various participants and shape their views on what actions are appropriate and conceivable (Scott, 2002). Consequently, certain actions embedded in a culture are often taken for granted and occur subconsciously.

When examining a widespread ethnic group across different industries and countries, particularly in locales whose regulatory regimes are not extensively developed, the cognitive aspects of an institutional system, transmitted primarily through the local culture, may hold the key to understanding the system's structure (Jepperson, 1991; Low, 2002). As noted before, the culture of the Overseas Chinese is known for its strong influence on managerial behavior and resulting differences from that of the West (Chen, 2001). Some recognition has been given to the importance of relationships, or guanxi, for commercial transactions in East Asia (Tsang \& Walls, 1998). The cognitive institutions, such as guanxi could be expected to similarly impact venture capitalists in East Asia, particularly those activities that involve intense interpersonal interactions, such as selecting firms for funding and monitoring those firms.

\section{Methodology}

\subsection{Research design}

To study the impact of institutions on venture capital and how venture capital in East Asia functions differently from that of the West, the researchers conducted a field study from 1998 to 2000 in the East Asian venture capital centers of Hong Kong, Singapore, and Taiwan. Focusing on these three regions meant reasonably consistent cognitive institutions could be expected since business is dominated by
Overseas Chinese in those economies, who share a common culture and set of commercial practices (Chen, 2001; Weidenbaum, 1996).

The data were gathered using semi-structured interviews, then assembled and coded in a manner broadly consistent with a grounded theory research design (Eisenhardt, 1989; Glaser \& Strauss, 1967; Strauss $\&$ Corbin, 1990). In grounded research the researchers seek to examine a topic through an iterative process of comparing data to a baseline framework or to a new theory as it emerges from the data (Strauss \& Corbin, 1990). Thus, interviews were used in this research for four reasons. First, the venture capitalists often preferred face-to-face interviews over questionnaires. Second, it is often necessary when examining East Asian related business activity to establish a relationship with respondents in order to receive a response, which also diminishes the usefulness of questionnaires. This connection may come through a referral. Prior to contacting the venture capitalists such connections often needed to be arranged. Third, interviews are less structured than are questionnaires as they allow the spontaneous discussion of problems and solutions and for follow-up questions on a topic with the development of recommendations (Frey \& Oishi, 1995; Lee, 1999). While we were specifically concerned with potential institutional effects on venture capital, we were also generally interested in understanding how venture capital works in East Asia. This method permits iteration and follow up as required in grounded theory. Finally, as this is a new area of study, the benefit of conducting in-depth interviews to develop a theoretical understanding of such a domain is well-established (Daft \& Lewin, 1990; Eisenhardt, 1989; Lee, 1999).

The inquiry framework was guided by an understanding of numerous agreed upon aspects of Western venture capital drawn from a variety of established sources in the domain (e.g., Fried \& Hisrich, 1994; Gorman \& Sahlman, 1989; MacMillian, Kulow, \& Khoylian, 1988; Sapienza, 1992; Zider, 1998). Various sources have come to agree on several aspects of the U.S. venture capital industry. There is also evidence that these findings are also largely applicable in Europe (e.g., Sapienza et al., 1996). The findings on the Western venture capital industry can be organized into four broad topical areas that will direct the domains examined in this research: the selection 
process for firms to be funded, the monitoring of funded firms, value added activities provided to funded firms, and exit of the investment.

\subsection{Sample}

The authors conducted a total of 60 semi-structured interviews with leading venture capital fund managers and other experts on venture capital in East Asia; there were an equal number of interviews in each region with the total sample representing approximately $25 \%$ of the venture capital firms active in the three regions at the time of the interviews. We followed a purposive sampling approach to the sample selection and subsequent follow up (Lincoln \& Guba, 1985). Purposive sampling calls for selecting participants with specific characteristics, such as extreme cases, typical cases, significant variation, or politically important cases (Lincoln \& Guba, 1985). The venture capitalists were initially identified from the Guide to Venture Capital in Asia (1998). They were selected to ensure both a range of firms both in terms of size (large and small venture capital firms) and origin (locally founded as well as internationally-based). In the final sample, the median amount of funds under management was U.S.\$ 110 million. At the high end, one firm had $\$ 700$ million under management while the smallest firm stood at $\$ 30$ million. In terms of specialty areas, in Taiwan, most firms specialized in electronics investments, although two were in life sciences. In Hong Kong, the firms invested in a wide range of sectors, although emphasis was on later stage investments such as property and infrastructure. There was some technology investing by Hong Kong venture capitalists, although mostly in Chinese language translation of popular U.S. Internet sites. Singapore was split evenly between private equity investments in established firms (hotels, property, infrastructure, consumer goods) and electronics; and thus Singapore lies between Taiwan and Hong Kong in venture capital emphasis.

In addition, we also interviewed the founders of four funded firms, two in Taiwan and one each in Hong Kong and Singapore, for additional insights on the venture capital process and to corroborate the information provided by the venture capitalists. These interviews helped to validate the results and provide some additional insights. Finally, we interviewed a government official in each location directly involved with promoting venture capital and technopreneurship for additional validation of the findings.

\subsection{Interview protocol}

As noted earlier the researchers wished to gain a broad understanding of venture capital practice in East Asia. Therefore, data were gathered through semistructured interviews employing a replication logic approach to the interviews (Eisenhardt, 1989). That is, after collecting descriptive information about the firm and the venture capitalist background, we asked the respondent a number of open-ended questions. These questions examined the four topical areas identified from the Western literature. In addition, all interview subjects were asked to consider the major findings from the West on venture capital and to what extent these applied in East Asia. Appendix A provides an outline of topics covered and the questions asked.

In the discussion that followed each succeeding interview the authors continued to employ replication logic to compliment the iterative, grounded research design (Eisenhardt, 1989). Thus, following the interviewee's overview of the venture capital industry in East Asia in the four topical areas and how the activities were different from the model presented from the West, the interviewers presented their summary of the emerging East Asian venture capital model based on previous interviews. The interviewee would then discuss how they agreed with or would clarify the emerging venture capital model to more accurately reflect what occurs in East Asia. After the interview, follow-up questions were often asked via the telephone or email. Thus, over the course of the interviews a consistent picture of venture capital in East Asia began to develop. We continued adding interviews in each country until incremental learning derived from the subjects became negligible (Glaser \& Strauss, 1967). ${ }^{4}$ This process is the same as the one used by Fried and Hisrich (1994) when they examined venture capital decision-making in the U.S.

In the subsequent interviews with funded firms, the interviewers asked senior managers in those firms the

\footnotetext{
${ }^{4}$ Diesing (1971) argued that six cases often provide such a number; however, in this study, it was felt that the greater number of venture capital interview subjects coupled with follow-up interviews with funded firms and government officials would provide greater validity of the results.
} 
same questions. In addition, we asked them to respond to the tentative conclusions drawn from the first round of interviews and our review of the relevant literature. ${ }^{5}$ Similarly, the government officials were also asked their views of venture capital and their assessment of the East Asian model of venture capital as supplied by the venture capitalists.

\subsection{Data analysis and validation}

Approximately half of the interview subjects were ethnic Chinese subjects, and their command of English was such that all but two of the interviews were conducted in English. The interviews conducted in Chinese were translated at the time of the interview by a native Chinese speaker present. In addition, to ensure reliability, the native Chinese speaker also took notes at the interviews and these notes were later examined to ensure the information obtained was accurate. If any discrepancy occurred, the interview subject would be contacted for clarification. For all interviews, the results were summarized and venture capitalists were subsequently contacted for corroboration.

All of the venture capitalists interviewed were responsible for funding decisions by their firms. In addition, all interview subjects of the venture capital firms were either a principal or a senior manager. For those in the funded firms, all those interviewed were firm founders. The government officials in the sample were also senior (at the departmental level) officials responsible for a variety of government venture capital initiatives in each of their respective three regions.

Interviews were coded for categories and subcategories by one investigator and one other researcher who was not part of the study. The initial categories were open coded (Strauss \& Corbin, 1990) consistent with the key concepts well understood in venture capital such as venture investment selection, due diligence and exit. ${ }^{6}$ Subsequent institutional con-

\footnotetext{
${ }^{5}$ More information is available from the authors on the interview protocol used.

${ }^{6}$ The interview protocol in Appendix A contains the primary (venture capital) categories used. Key subcategories - constructs that operationalized the primary venture capital action categories such as due diligence, emerged from the data. Additional coded categories illustrating likely institutional effects also emerged. Representative quotes from these categories and their proposed effects are reported in the results section and summarized in Table 2.
}

structs were then coded and how they likely impact the main venture capital concepts were then identified and are summarized in Table 2 . Reliability proved to be about ninety percent between the two coders, and there was also much agreement among the interview subjects. The results from each country were compared and a high degree of consistency was found as well. The summary findings were also shared with other leading venture capitalists in East Asia that were not part of the sample to get their observations and comments on the findings. To further validate the results, information was gathered from other sources such as industry authorities and government officials responsible for investment and industrial policy to further corroborate the data gathered. In general there was great consistency in the evidence gathered from all sources on all issues examined, though where disagreements occurred, these are also reported in the results. When there were additional observations and some differences, we have supplied those opinions and discuss explanations for these differences. These are all summarized in Table 2.

In summary, apart from the replication logic used in building the model (Eisenhardt, 1989), there were three additional means by which the research findings were validated: (1) funded firms within each country were interviewed to ensure that the model developed accurately represented venture capital practice in that region; (2) government officials in all three regions were interviewed to provide validation and additional observations of the model; and (3) other prominent venture capitalists and industry participants not involved with this research were contacted to assess the findings. These three sources all confirmed the accuracy of the results and interpretation while providing some amplification; these models of venture capital beliefs and behavior in turn were also generally consistent across countries. When some differences of opinion or emphasis emerged these have been reported in the results and summarized in Table 2.

\section{Results}

The results are discussed below in terms of how each category of institutions impacted the various activities of venture capitalists in East Asia, highlighting key differences from that of the West. Results are first 
Table 2

Institutional forces in the U.S. and East Asia on venture capital

\begin{tabular}{|c|c|c|c|}
\hline & U.S. & East Asia & Additional observations and dissenting views \\
\hline Regulatory & $\begin{array}{l}\text { Strong legal framework, } \\
\text { generally transparent and } \\
\text { well-regulated financial markets, } \\
\text { and effective corporate governance } \\
\text { system with strong protection } \\
\text { for institutional investors and } \\
\text { minority shareholders. }\end{array}$ & $\begin{array}{l}\text { Legal system and corporate } \\
\text { governance mechanisms are } \\
\text { relatively weak, but are moving } \\
\text { toward Western common law } \\
\text { standards. Reporting standards } \\
\text { remain lax, more cross holdings, } \\
\text { insider control of information } \\
\text { and insider action based on } \\
\text { financials, representing a concern } \\
\text { to most of the venture capitalists. } \\
\text { Improper action by funded } \\
\text { firm principals more difficult } \\
\text { to monitor and control. }\end{array}$ & $\begin{array}{l}\text { Most of the venture capitalists felt that the legal } \\
\text { systems in Hong Kong, Singapore and Taiwan } \\
\text { were not an overwhelming problem for them, } \\
\text { in spite of the weaker reporting, corporate } \\
\text { governance and disclosure requirements. } \\
\text { Two venture capitalists pointed out, however, } \\
\text { that the courts were not a remedy available } \\
\text { to them, and it was important to solve } \\
\text { contractual conflicts and other problems } \\
\text { outside of the courts. }\end{array}$ \\
\hline Normative & $\begin{array}{l}\text { Professional standards play an } \\
\text { important role in defining } \\
\text { acceptable venture capital } \\
\text { activities. }\end{array}$ & $\begin{array}{l}\text { Professional standards similarly } \\
\text { play an important role in defining } \\
\text { business activities. Venture capital } \\
\text { associations hold training and } \\
\text { encourage certain professional } \\
\text { standards. Similar educational } \\
\text { training and normative standards } \\
\text { as U.S. venture capitalists. }\end{array}$ & $\begin{array}{l}\text { There was general agreement that the professional } \\
\text { standards of Western venture capitalists were an } \\
\text { ideal to be pursued and were reasonably upheld } \\
\text { in East Asia. The government officials interviewed } \\
\text { agreed and encouraged venture capital training } \\
\text { consistent with the Western model. Several venture } \\
\text { capitalists dissented somewhat, stating that the } \\
\text { realities of East Asian business dictated that } \\
\text { venture capital firms, if not the venture } \\
\text { capitalists themselves, behave somewhat differently. } \\
\text { This was particularly true with the need to monitor } \\
\text { investments extra carefully, and to usually have staff } \\
\text { based in the same locality where deals are funded. }\end{array}$ \\
\hline Cognitive & $\begin{array}{l}\text { Strong emphasis on investor } \\
\text { and shareholder rights. } \\
\text { The importance of transparency, } \\
\text { disclosure and the role of } \\
\text { outsiders are well accepted. }\end{array}$ & $\begin{array}{l}\text { Strong influence of Chinese culture } \\
\text { in much of East Asia. Emphasis } \\
\text { on maintaining guanxi networks. } \\
\text { Harmony with organizations and } \\
\text { lack of disclosure of information } \\
\text { can take primacy over shareholder } \\
\text { rights. Outsiders not easily trusted } \\
\text { and a high level of information } \\
\text { asymmetry is still tolerated. }\end{array}$ & $\begin{array}{l}\text { Most venture capitalists agreed they try to get to } \\
\text { know the principals of funded firms as part of } \\
\text { due diligence process. One venture capitalist added } \\
\text { that guanxi was less helpful in securing funding, but } \\
\text { it was a necessary part of monitoring the firm. } \\
\text { Government officials argued that guanxi was no } \\
\text { longer important in securing funding as the business } \\
\text { models needed to be attractive, but they did not } \\
\text { comment on the monitoring process. }\end{array}$ \\
\hline
\end{tabular}

presented and additional insights on the impact of those types of institutions on the actions of venture capital are presented, and that is followed by a proposition to summarize the findings. Any disagreements or differing interpretations are also discussed.

\subsection{Regulatory elements}

The regulatory elements reflect laws and sanctions that regulate the behavior of firms and individuals (North, 1990). Regulatory processes involve the setting of rules and their enforcement. Taiwan, Hong
Kong and Singapore all possess some different laws concerning venture capital. The regulatory dimension in the three regions was consistently found to have an impact on how East Asian venture capitalists fund new firms. It was also found that the regulatory dimension also significantly impacts exit from the funded firms. Each of these findings will be reviewed in turn.

\subsubsection{Investment selection}

In the West venture capitalists rely on financial and accounting information contained in the business plan to initially evaluate the proposal (McGrath, 1997; 
Wright, Thompson, \& Robbie, 1992). ${ }^{7}$ Additionally, venture capitalists in the West use information present in the plan to assess the risk of the proposed ventures (Wright et al., 1992). While venture capital firms in East Asia prefer to fund firms that have established financials, the regulatory institutions (items set by law) impact the quality of the information presented. Timely, accurate, or useful information about the financial performance can be difficult to obtain. Thus, if a firm is not already established (three years of financials) the risks are typically considered too high for funding in East Asia, unless the firm's technology and business plan is exceptional.

The selection process is also made more challenging by the difficulty of obtaining reliable data from which to conduct due diligence. One Singapore based venture capitalist commented "since investors have less protection here [in Singapore] than in the West, it helps to have other means to screen and select and investments." The venture capitalists generally agreed that as legal protection against fraud is weaker and market and accounting information have numerous deficiencies in East Asia, it is helpful to know the principal of the funded firm and his or her family. Added another Singapore-based venture capitalist, "this provides added protection as the firm principal is less likely to disappear or drop out of the investment because you know that individual as well as his or her family." Observed another Singapore-based venture capitalist:

... I apply [the importance of relationships] to venture capital and private equity deal making, both on the hiring side and investing side. For example, I love to do deals with people I have done deals with before. So you will find that although we might have done sixty or seventy transactions over the years, they have not been done with sixty or seventy different entrepreneurs, they have been done with twenty-five to thirty entrepreneurs. Many of them are repeat deals. The biggest risk in our business ... is the people risk and when you do a repeat thing with the guy you have a good experience with,

\footnotetext{
${ }^{7}$ This is particularly true for more mature firms such as those funded in East Asia. The business model and founding team are more critical the earlier the venture is funded. However, as noted previously, most funded businesses in Asia are relatively mature when compared to the U.S.
}

you have eliminated what I consider the biggest risk in the business-the people risk.

Thus, while knowing firm principals, or knowing people that do, in the West is important in East Asia it was deemed so significant that it was a barrier that is difficult to surmount, if not impossible to overcome, in the selection process across East Asia. Overall, the selection process proved more difficult than in the West because the data that enables due diligence may not be readily available in East Asia. In addition, the absence of many legal protections and lack of case precedent in these countries generally make the enforcement of the contracts more difficult if problems arise. ${ }^{8}$ Thus we propose:

Proposition 1: The less developed regulatory institutions in East Asia often leads to an absence of valid and reliable information on a firm seeking funding. As a result the selection process of firms to fund is more difficult and time consuming for venture capitalists in East Asia.

\subsubsection{Exit}

Another area that the weakness of regulatory structures impact is exit from the venture. In the West venture capital firms are usually organized as limited partnerships with a fixed life (Sahlman, 1988). Thus, the goal of most venture capital firms is to exit their investments through initial public offering (IPO) in five to seven years. Most private equity investors in East Asia also expect to exit through IPOs or strategic sales of the funded firm, although a shorter time frame of two to three years is common since the ventures that are funded are typically more mature in East Asia. However, exiting can be problematic, even from successful, growing ventures.

In Taiwan the TASDAQ is fairly well established but in Hong Kong and Singapore it is considered more difficult for young firms to obtain a listing on a stock market, and even when it does occur it usually takes much longer (Wang \& Sim, 2001). Thus venture

\footnotetext{
${ }^{8}$ Although Singapore in particular has been working to develop new laws to cover venture and private equity investment, much remains to be done in East Asia terms of getting more laws on the books as well as enforcing them properly. Sometimes laws from other jurisdictions such as California are relied upon for certain deals if local laws are not seen as inadequate.
} 
capitalists pointed out that a more frequently employed exit strategy in these locales is to have the firm locate a strategic buyer. However, finding such ideal strategic partners can be challenging, and when exiting via a sale to a strategic partner, the multiple paid on the firm's revenue stream results in a return significantly lower than that traditionally associated with an IPO.

One result of these exit difficulties is that many venture capital firms have discovered that when they do exit, their returns have not been as high as expected. Private equity firms in East Asia regularly reported a target of 20-30\% return, but actual returns for many funds have been much lower (Asia Pacific Private Equity Bulletin, 1998). A number of different regions have announced the introduction of NASDAQ-type markets for smaller firms, such as Taiwan's TASDAQ and Hong Kong's Growth Enterprise Market (GEM). These new markets may help alleviate the exit problem for venture capitalists to some degree. Nevertheless, because of reduced liquidity in the market and stricter listing laws exit through an IPO is far from straightforward (Wang \& Sim, 2001). Thus we propose:

Proposition 2: The underdeveloped regulatory institutions in East Asia suppress the development of listing mechanisms for new startup firms. The resulting exit from funded ventures in East Asia will be more constrained and complex for the venture capitalist than in the West.

\subsection{Normative elements}

The normative elements of an institutional system are those well-accepted values, beliefs and practices shared by professions, groups and opinion leaders in a field, often propagated through education, textbooks, training and consulting (DiMaggio, 2001; Scott, 1995). Venture capital requires extensive interaction between the venture capitalist and the entrepreneur they fund. Particularly, the monitoring of the funded firm requires extensive interaction since the published information may not provide an accurate indication of the firm's performance. Thus, the normative values of the venture capitalist and how these values interact with those of the funded entrepreneur in monitoring the firm will be reviewed in turn.

\subsubsection{Values}

East Asian venture capital norms generally proved similar to what is known about venture capitalists in the West from authors such as Fried and Hisrich (1995). The venture capital industry in East Asia developed principally as individuals and firms from the U.S. and Europe moved into East Asia. The result is that most venture capitalists in East Asia have worked for or been trained in the U.S. or Europe. Additionally, venture capital associations hold training programs throughout East Asia that encourage professional standards that are very similar to U.S. venture capitalist. These two factors help to produce a set of normative values among the venture capitalists very consistent with those from venture capitalists in the West. ${ }^{9}$ Thus we propose:

Proposition 3: Normative values of venture capitalists in East Asia will generally be very similar to those found in the West.

\subsubsection{Monitoring}

The venture capitalist must interact with entrepreneurs of funded firms extensively in monitoring investments. Thus, the normative values of indigenous entrepreneurs must also be considered in examining the venture capitalist actions in this domain (Lau et al., 2002). The result is that one key difference in normative practice from that of the West that emerged in East Asia is that monitoring is done much more through personal interactions with the entrepreneur who founds the firm.

In the West venture capitalists monitor their investment mostly through direct interaction with the entrepreneur. However, venture capitalists and the entrepreneur know that they will also monitor the investment through firm financials and via the venture capitalist's membership on the board of directors (Fried, Bruton, \& Hisrich, 1998; Fried \& Hisrich, 1992, 1995; Rosenstein, 1988; Sapienza, 1992). Accounting rules and reporting standards around East Asia can deviate significantly from international norms (Broadman, 1999; Low, 2000; Peng, 2000). Even in those cases that there are financials produced by one of the established international accounting firms, there can be considerable concerns about the

\footnotetext{
${ }^{9}$ This does not necessarily mean the skill levels are the same; instead, it simply means they have similar values.
} 
validity of the information presented. As one venture capitalist interviewed recalled, "just because there are audited statements from an international accounting firm does not mean there are not multiple sets of books in the firm." Another venture capitalist added that you should be prepared to go into a firm and count things yourself. Thus, the normative values of entrepreneurs help to shape the utility of the company information that the venture capitalist will receive.

In terms of monitoring via the board, it cannot be assumed that the venture capitalist will receive a board seat in East Asia (Low, 2002). But even if a board seat is obtained it may not mean what it does in the West. As noted, corporate governance is weak in the three regions examined with only limited influence of outside directors (Peng, 2000). Additionally, the information received may be less than accurate. For example, one venture capitalist reported that it is not uncommon for the minutes of board meetings to be written before the meeting has actually started, complete with readymade quotes from that venture capitalist.

Therefore, some of the traditional means to monitor the funded firm in mature economies such as obtaining regular accounting and financial information and board membership may provide fewer insights in East Asia. If the venture capitalists are to properly monitor their investment they must develop trust with the entrepreneur so that they obtain the desired information and ensure its accuracy. Such trust between the funded firm and the venture capitalist is consistent with the nature of communication between parties in Chinese culture. In this cultural setting there are typically clear insiders and outsiders (Goa, Ting-Tooney, \& Gundykunst, 1996), and the flow of information to outsiders is severely restricted. Several venture capitalists reported that they had to work very hard to build trust with their funded firms to secure even a modicum of information. Some of the same monitoring approaches used in the West are relevant, while other different circumstances and practices in East Asia compel venture capitalists to monitor investments differently, specifically focusing on building a relationship with the entrepreneur for which the project is funded. Thus we propose:

Proposition 4: The normative values of funded entrepreneurs result in monitoring activities in East Asia that require venture capitalists to place emphasis on having or building relationships with funded entrepreneurs. The result is that the monitoring time, effort and costs will be higher than those for venture capitalists in the West.

\subsection{Cognitive elements}

The cognitive elements of institutions are commonly transmitted through culture, of which in Hong Kong, Singapore, and Taiwan, is predominantly the culture of the Overseas Chinese (Chen, 2001; Jepperson, 1991; Scott, 2002). Overseas Chinese culture particularly impacts actions of managers by imparting greater importance to relationships among business people, thus impacting how venture capitalists can add value to funded firms (Chen, 2001).

The interviews revealed that the venture capitalists see the cultural/cognitive institutional elements (Scott, 2002) as having a great impact on their day to day activities. For example, these elements have a significant impact on the nature of the value added venture capitalists can provide to funded firms. The interviewees stressed the U.S. venture capital industry influences their training. The terms they used, their goals, and the values they expressed as to what the appropriate actions were for venture capitalists were generally consistent with those expressed by venture capitalists in the U.S. However, it was clear in these discussions that the venture capitalists in East Asia also are influenced by the environment in which they compete. The weaker regulatory system in East Asia in particular means that the culture of the region may become even more important in assuring that the actions desired are actually pursued (Chen, 2001). The ability of venture capitalists to compel a funded firm to perform certain activities is constrained by the weaker legal and enforcement regime in East Asia. Thus, culture as a means of influencing behavior becomes even more salient. Reflected one Singapore venture capitalist:

In the [United] States, you have laws that people respect and are enforced. In Asia, that is often not the case. At our company, we try to do deals with people we know, or others know. And it helps if [the entrepreneur's] family is here also. Then we can get to know them. This way, it makes it harder for people to slack off, or even skip town with our money. We can always go to his family and ask what is 
happening with their son. They usually will not want to be embarrassed... This [influence of the family] is helpful with our due diligence and monitoring.

When examining a widespread ethnic group across different industries and countries, particularly in locales whose regulatory regimes are not extensively developed, the cognitive-based institutions, transmitted primarily through the local culture are a focus of concern (Chen, 2001; Jepperson, 1991; Peng \& Heath, 1996). As noted before, the culture of East Asia has already been known for its strong influence on managerial behavior resulting in actions that differ from what would occur in similar situations in the West (Chen, 2001). Two particularly important aspects of cognitive institutions will be examined in turn.

\subsubsection{Guanxi}

One particular cultural issue stood out in the interviews. It was noted previously that the commercial regulatory regime in East Asia is still weak in many areas. One means that has developed to assure performance across a wide range of businesses is that there should be a relationship of some type between the parties. The relationship may not be sufficient to assure that the business activity between the two parties occurs but it is a necessary condition before the business activity is even considered. This relationship can be such that the parties went to the same school, their families are friends, they are related, or share significant business interests with others.

The effect of such relationships is that cultural control is established. As a result, in East Asia some relationships between the venture capitalist and the funded firm's top management may have to be present for funding to be considered. Relationships between venture capitalists and their relevant networks of investors, entrepreneurs, and other venture capitalists are also important in the U.S. (Bartlett, 1995), but in East Asia guanxi or connections between various parties are particularly crucial. Guanxi is very helpful to the venture capitalist in conducting due diligence, successfully interacting with the firm, and ensuring the firm achieves the desired results.

Thus we propose:

Proposition 5: Cognitive institutional elements in East Asia will result in the actions of venture capitalists being particularly impacted by the consequences of guanxi.

\subsubsection{Value added to funded firm}

803

One of strengths of venture capital in the West is the value added to the firm by the venture capitalist (Bygrave, 1987; Zider, 1998). Providing value added to the firm through advice and services provided is also increasingly the case in East Asia's venture capital industry (Ahlstrom et al., 2000). However, this is a recent change. Initial private equity investors tended to be passive financial investors. But, increasingly, the interest is to provide added value to the firm in a manner consistent with venture capitalists in the West.

In the U.S., for example, the advice provided to the $\mathrm{CEO}$ of the funded firm is often very direct and may occur in regular interaction between the venture capitalist and the CEO (Fried \& Hisrich, 1995). However, in East Asia the manner in which the venture capitalist typically provides the advice to the CEO is different. As noted, the CEO of the firm culturally plays a paternal role that impacts the flow of information and organization. Thus, the venture capitalist in East Asia must deal appropriately with the key cultural factor of minzi-face or respect. In other words, the appearance of appropriate difference to an individual's status in the society and the firm. It is arguable that even in the West the issue of face is important. However, its relative greater importance in a Chinese-based culture is widely recognized (Bond, 1988). Additionally, in Chinese culture there is a bias to avoid conflict. Therefore, several venture capitalists indicated that one needs to advise a manager in a manner that allows the maintaining of face and avoiding of conflict. For example, rather than giving an ultimatum, an idea might be put forth as a suggestion. One Hong Kong venture capitalist commented:

The setting where suggestions are provided is important. A venture capitalist should never make bold suggestions in front of a manager's subordinates. The venture capitalist should take the manager aside and make the recommendation in private. This way, the manager can remain 'in charge' and take credit for the changes. It is important to give face to the entrepreneurs you fund-some are very sensitive to this. 
Thus we propose:

Proposition 6: Cognitive institutional elements in East Asia exert strong influence on the manner in which value is added to the firm by venture capitalists.

\section{Discussion}

The evidence here suggests that a range of institutional elements present in East Asia influence the actions of venture capitalists located in the region, in spite of similar training and norms as venture capitalists in the West. These institutions create several differences from venture capital practice in the West that venture capitalists and investors need to be aware. The institutional elements (regulatory, normative, cognitive) can all exert influence; however, the less formal cognitive institutional elements may play the strongest role. In particular, the cognitive institutions as exemplified by the Overseas Chinese commercial culture strongly shape the behavior of the venture capitalist in East Asia.

The Western and East Asian models of venture capital developed within very distinct institutional frameworks (Scott, 1995, 2002). In East Asia the distinguishing characteristic includes the fact that most East Asian economies have a deeply entrenched concentrated ownership structure, with significant family control of firms, and interlocking shareholdings among firms, characteristic of Overseas Chinese business practice (Allen, 2000; Chen, 2001; Zhuang, 1999). These normative and cognitive institutions combine with the weak regulatory system and poor corporate governance (regulatory institutions) to create different and unusual challenges for venture capitalists working in East Asia.

These distinctive institutions have led to many differences in the implementation of the various activities by the venture capital industry in East Asia. For example, the nature of the regulatory institutions means venture capitalists must conduct due diligence as part of their firm selection quite carefully. One Singapore-based venture capitalist related a story that during a due diligence investigation it was found that a funded firm failed to have much of the inventory that was stated on its books. The inventory was actually being held by a sister firm in a different part of
SouthEast Asia. When asked about it, the funded company founder retorted that the inventory was still under its control, albeit some 1,500 kilometers from where it was reported to have been, and that there was nothing to worry about. The lack of regulatory institutions and sometimes different commercial norms makes close monitoring of funded firms quite important in East Asia, albeit challenging.

Venture capitalists in the three regions examined often fund businesses that have some activities in Mainland China as well. The difficulties in implementing venture capital activities there are even more severe because of the paucity of laws and their enforcement in many industrial sectors (Ahlstrom, Young, \& Nair, 2002; Bruton \& Ahlstrom, 2002; Lubman, 1999). To illustrate, the need for due diligence in China is even more critical since assets can gradually or even suddenly disappear if not watched carefully, with the complicity of the local law enforcement (Ahlstrom et al., 2002). For example, one Hong Kong-based private equity firm helped to fund an existing business that was long established. However, due to the inability to properly do (personal) due diligence and monitor the China-based firm, the private equity firm found that one day that firm had closed without any warning to anyone and the entrepreneur had taken everything of potential value from the funded firm. He even carted off all the porcelain toilets bathroom fixtures from every floor of the building.

The nature of the normative institutional elements present in the East Asian region also can impact the implementation of some common venture capital activities. For example, the difficulty in gathering needed information to monitor funded firms has led many venture capitalists to focus their efforts primarily on given geographic areas where they know people and can travel to regularly, rather than on specific industries as would be more common among venture capitalists in the West (Bruton et al., 2001). Additionally, the strong role of the owner/manager leads the individual to often view the funds provided by the venture capitalist to be their personal funds. One venture capitalist related how this view resulted in expenditures for houses and cars. Thus, venture capitalists must closely monitor the funds expenditures to ensure they are spent as intended.

Similarly, owner/managers in the region see venture capitalists only as passive financial investors. Historically this has often been the role the venture capital 
industry was reduced to playing. However, today venture capitalists are seeking to be more active investors and provide value to the funded firm on different levels (Gupta, 2000). Thus, the venture capitalists today must often educate entrepreneurs about the venture capital process and their expectations.

The cognitive element of guanxi also relates to another key implementation issue. For example, venture capitalists need to ensure that they understand not only the prospective funded firm's business model and capabilities, but also any local-partner relationships, and government connections the firm top management team (particular its founder) has. As one venture capitalist put it:

In a business situation, try to understand the context of the word 'friend' or pengyou to learn what level of influence or actual guanxi really exists and whether your friend has the interest to use his or her friendship for you or for others to your benefit.

Without the benefit of such guanxi or connections, the ability to judge the credit worthiness of the entrepreneurs and their idea is limited. Additionally, without such connections the ability to accurately monitor the funded firm can also be insufficient. The role of such connections also means that new venture capital firms must be careful to include key individuals who have such an understanding, or the venture capital firm will be at a disadvantage until it can build the necessary connections. Institutions in East Asia and their influence as compared to those of the West are summarized in Table 2.

It is important to note that while there were broad similarities in the venture capital industries in the three countries examined there were also subtle differences. Among the three regions the Taiwanese industry was most focused on high technology investing. Thus, it was in Taiwan where high risk, high return venture capital investing was most likely to occur. For example, there is an established (although not closely regulated) gray market for shares of technology-focused firms prior to their public listing in Taiwan. The result of this market is that there is some exit opportunities for venture capitalists not available in the rest of Asia.

Similarly, the role of the government in the venture capital industry in Singapore differs from that of the other two governments. The Singapore government provides an important part of the venture capital available in Singapore. The government has a nonintervention attitude towards the management of these funds. However, the government does encourage the funds to seek out international opportunities in the U.S. and Europe for investment. The belief is that such investments will strengthen the normative values of the venture capital industry in that nation and align them more with those of the venture capital industry in the West. As a result the Singapore venture capital industry is more focused on ensuring values and behaviors consistent with those in the U.S. or Europe. Thus, there are subtle but pervasive differences in the venture capital industries even in the three regions examined. Future research should examine these differences among other topics in the future.

\subsection{The future of venture capital in East Asia}

There are significant differences between the venture capital industries of the West and East Asia. At the end of the interviews the venture capitalists and government officials also discussed their view of the future of venture capital in East Asia. Specifically, they focused on whether the differences identified here will persist over time or whether the Western and East Asian industries will converge in the future.

As noted before, the normative values of the venture capitalists in the West and in Asia are generally similar due to the nature of their training and propagation of professional standards. However, it came clear in the resulting discussion there are other changes occurring among the normative institutions of the entrepreneurs in East Asia that are driving the venture capital industry in the West and Asia closer. The firms coming forward to ask for funding are no longer focused in more mature and primary resource industries. Instead, a variety of technopreneurial startups are increasingly considered for funding by venture capitalists in the East Asia.

Moreover, the nature of the entrepreneurs coming forward to ask for funding is changing. Historically, most of the top graduates from universities in the region sought to go to work for large corporations. Today however, the best and the brightest from universities are increasingly seeking to start their own firms, particularly in high technology areas. These students' models are great entrepreneurs from the West such as Bill Gates and Steven Jobs so they seek to act accordingly. Additionally, increasing numbers 
of prospective entrepreneurs are returning from universities in the West and are bringing new ideas and expectations for the venture capitalist with them. Finally, since many of the firms have a strong technology focus, the need for such businesses to more fully integrate and cooperate with other firms around the world encourages the firms to become more like those firms. Thus, firm selection can increasingly be expected to become more similar to the West.

Additionally, entrepreneurs also increasingly understand that the venture capitalists can offer financial and strategic managerial advice that will help firms achieve their goals. Thus, they are more willing to share information with the venture capitalists and take their value added activities. There are changes in the institutions in East Asia that are providing means for these entrepreneurs to have their new startups publicly listed which, in turn, helps to increase the interest of high quality individuals. The opening in the region of exchanges such as Hong Kong's new Growth Enterprise Market stock market has created opportunities for entrepreneurs that did not exist before. The result is that the role of monitoring and exit will also become more similar to the West in the future. Thus, overall, it is likely that venture capitalists in East Asia will increasingly behave in manners very similar to their counterparts in the West. There are, however, institutional forces in East Asia that will continue to differ from those of the West. Although there are efforts in East Asia to change some of the laws and to improve enforcement and corporate governance, for instance, significant differences between the institutional profiles of the West and East Asia remain. These differences will mean that the practice of venture capital in East Asia will continue to vary from that of the West.

\subsection{Future research}

In the future greater effort should be made to explore East Asian venture capital, particularly in terms of the range of the issues raised here. Issues such as how venture capital financing is structured, the governance mechanisms that are employed, and, related to this, the character of the board of directors in the funded firm should be explored. Additionally, the nature of the value added services provided to the funded firm would be of interest. Historically, business in East Asia is heavily based on relationships. Does this reliance on relationships reduce or increase the role of venture capitalists as a source of such connections? The role of the strong leader is particularly salient in East Asia; does this role change when the funded firm is in a high technology domain? In the past such strong leaders were sensitive to not release too much control to outsiders. It is possible that this role changes in high technology concerns. Finally, how does the addition of the new exchanges in East Asia change the nature of exit?

The economies of East Asia are playing a bigger part in the world economy. The ability to understand business in this region, particularly entrepreneurial activity will provide key insights regarding this important part of the world economy (Peng, 2000). It is especially important for managers and investors from the West to understand how institutions in different regions such as East Asia impact business and investment in those regions (Tsui \& Lau, 2002). It is known that venture capital is crucial for entrepreneurial and industrial development (Timmons, 1999). Thus, by continuing this exploration of East Asian venture capital, greater insight should be possible regarding this vital region of the world, its emerging firms and its salient institutions and ways of doing business.

\section{Uncited references}

Backman (1995), Boeker (1992), Claessens, Djankov, and Lang (2000), Daily and Dalton (1995), Dalton, Daily, Ellstrand, and Johnson (1998), Davies, Leung, Luk, and Wong (1995), Faccio, Lang, and Young (2001), Fiet (1995), Great expectations (1998), Jayasankaran (2000), Kao (1993), Peng, Luo, and Sun (1999), Pratt's guide to venture capital sources (2000), Rohwer (2001), Sapienza and Gupta (1994), Standifird and Marshall (2000), The Economist (2000), Walsh and Kosnik (1993), Webb-site.com (1999), Xin and Pearce (1996), Yeung and Tung (1996), and Young, Ahlstrom, Bruton, and Chan (2001).

\section{Acknowledgments}

The work in this article was substantially supported by a grant from the RGC Research Grant Direct Allocation Scheme (Project no. 2070212, 2000-2001) of 


\section{Appendix A. Interview protocol outline and follow-up questions ${ }^{10}$}

1. Please broadly describe the general venture capital process in East Asia together with your views on similarities and differences with venture capital activity in the West.

2. Please describe the process for finding and selecting firms to fund. This includes how your firm conducts due diligence.

3. Please explain how you monitor funded firms. For example, how often do you visit your funded firms and what do you check on when you visit them? What kind of regular documentation do you require from funded firms?

4. Does your firm typically take a board seat? Are you on any boards of funded firms? Please tell us about your role on the board of funded firms.

5. Please tell us about any problems with corporate governance? About management fraud?

6. Please discuss the type of assistance that you provide to your funded firms. Is the assistance strategic or operating in nature? Can this help include forming alliances with other funded firms?

7. Please describe the exit options available to for your 156 funded firms and how you help them with this?

1158 with a funded firm.

1159 9. Were there any challenges in performing venture 1160 capital activities in your view that were related to 1161 what is thought of as the more traditional 1162 approaches to doing business in East Asia?

1163 10. Please highlight any other differences from the 1164 Western model of venture capital.

\footnotetext{
${ }^{10}$ More information is available from the authors on the interview protocol used.
}

11. (For the funded firm principals and government officials): Please evaluate and discuss the answers given by our sample. Tell us where you agree or disagree with the general consensus of venture capitalists regarding the venture capital process in your region. 11

12. Please comment on the model of East Asian venture capital as previous interview subjects have described.

13. Please provide us with the following basic information about your firm: (a) how many employees do you have? (b) how much do you have under management right now? (c) what funds have you managed in the past and have you closed any previous funds? (d) what industrial sectors or geographic regions do you emphasize? (e) are there any industrial sectors or geographic regions that you exclude and why? (f) how many employees work full-time on due diligence?

14. How do you give assistance to funded firms?

15. In what way have you helped firms with the scalability of their products or services?

16. Please give us your view of the future of venture capital in East Asia.

\section{References}

Ahlstrom, D., \& Bruton, G. D. (2001). Learning from successful local private firms in China: Establishing legitimacy. Academy of Management Executive, 15(4): 72-83.

Ahlstrom, D., Bruton, G. D., \& Chan, E. S. (2000). Venture capital in China: Ground-level challenges for high technology investing. Journal of Private Equity, 3: 45-54.

Ahlstrom, D., Young, M. N., \& Nair, A. (2002, NovemberDecember). Deceptive managerial practices in China: Strategies for foreign firms. Business Horizons, 45: 49-59.

Allen, J. (2000). Code convergence in Asia: Smoke or fire? Corporate Governance International, 3(1): 23-37.

Ang, S. H., Lee, S. H., Lim, G. H., Singh, K., \& Tan, K. Y. (2000). Surviving the new millennium: Lessons from the Asian crisis. Singapore: McGraw-Hill.

Asia Pacific Private Equity Bulletin. (1998). Hong Kong: Asia Pacific Communications Ltd.

Backman, M. (1995) Overseas Chinese business networks in Asia. Australia: Department of Foreign Affairs and Trade.

${ }^{11}$ In the interviews with the four funded firms and three government officials responsible for encouraging venture capital, we asked them the same questions. In addition, we asked them to respond to the tentative conclusions drawn from the first round of interviews and our review of the relevant literature. 
Backman, M. (1999). Asian eclipse: Exposing the darks of business in Asia. Singapore: Wiley.

Bartlett, J. W. (1995). Equity finance: Venture capital, buyouts, restructurings and reorganizations (2nd ed.). Singapore: Wiley.

Berger, D. L., \& Lickman, T. (1967). The social construction of reality. New York: Doubleday.

Boeker, W. (1992). Power and managerial dismissal: Scapegoating at the top. Administrative Science Quarterly, 37(3): 400-421.

Boisot, M. H., \& Child, J. (1988). The iron law of fiefs: Bureaucratic failure and the problem of governance in the Chinese economic reforms. Administrative Science Quarterly, 33: 507-527.

Boisot, M. H., \& Child, J. (1996). From fiefs to clans and network capitalism: Explaining China's emerging economic order. Administrative Science Quarterly, 41: 600-628.

Bond, M. H. (Ed.). (1988). The cross-cultural challenge to social psychology. Newbury Park, CA: Sage.

Broadman, H. G. (1999). The Chinese state as corporate shareholder. Finance \& Development, 36(3): 52-55.

Bruton, G. D., Ahlstrom, D., \& Singh, K. (2002). Venture capital in Singapore: Its unique position in Asia, and its future. Venture Capital: An International Journal of Entrepreneurial Finance, 4: 197-218.

Bruton, G. D., Dattani, M., Fung, M., Chow, C., \& Ahlstrom, D. (1999, Winter). Private equity in China: Differences and similarities with the western model. The Journal of Private Equity, 1: 7-13.

Bruton, G. D., Manigart, S., Fried, V., \& Sapienza, H. (2001, June 28-29). Venture capitalists in the United States, Europe and Asia: The impact of institutional forces. In Proceedings of the Conference on Technological Entrepreneurship in the Emerging Regions, Singapore.

Busenitz, L. W., Gomez, C., \& Spencer, J. W. (2000). Country institutional profiles: Unlocking entrepreneurial phenomena. Academy of Management Journal, 43: 994-1003.

Bygrave, W. D. (1987). Syndication investment by venture capital firms: A network perspective. Journal of Business Venturing, 2: 139-154.

Child, J. (2000). Theorizing about organization cross-nationality. In J. L. C. Cheng \& R. B. Peterson (Eds.), Advances in international comparative management (Vol. 13, pp. 27-75). Greenwich, CT: JAI Press.

Claessens, S., Djankov, S., \& Lang, L. H. P. (2000). The separation of ownership and control in East Asian corporations. Journal of Financial Economics, 58: 81-112.

Chen, M. J. (2001). Inside Chinese business: A guide for managers worldwide. Boston: Harvard Business School Press.

Daft, R. L., \& Lewin, A. Y. (1990). Can organization studies begin to break out of the normal science straightjacket? Organization Science, 1: 1-11.

Daily, C. M., \& Dalton, D. R. (1995). CEO and director turnover in failing firms: An illusion of change? Strategic Management Journal, 16(5): 393-400.

Dalton, D. R., Daily, C. M., Ellstrand, A. E., \& Johnson, J. L. (1998). Meta-analytic reviews of board composition, leadership structure, and financial performance. Strategic Management Journal, 19(3): 269-290.
Davies, H., Leung, T. K. P., Luk, S. T. K., \& Wong, Y. H. (1995). The benefits of "guanxi". Industrial Marketing Management, 24: 207-214.

Diesing, P. (1971). Patterns of discovery in the social sciences. Chicago: Aldine-Atherton.

DiMaggio, P. (2001). Conclusion: The futures of business organization and paradoxes of change. In P. DiMaggio (Ed.), The twenty-first century firm (pp. 210-243). Princeton: Princeton University Press.

Eisenhardt, K. M. (1989). Building theory from case study research. Academy of Management Review, 14: 532-550.

Faccio, M., Lang, L. H. P., \& Young, L. (2001). Dividends and expropriation. American Economic Review, 91(1): 54-78.

Fiet, J. O. (1995). Reliance upon informants in the venture capital industry. Journal of Business Venturing, 10(3): 195-223.

Fried, V. H., Bruton, G. D., \& Hisrich, R. D. (1998). Strategy and board of directors in venture capital backed firms. Journal of Business Venturing, 13: 493-503.

Fried, V., \& Hisrich, R. (1992). Venture capital and the investor. Management Research News, 4: 28-40.

Fried, V., \& Hisrich, R. (1994). Towards a model of venture capital investment decision making, financial management. Financial Management, 23(3): 28-37.

Fried, V. H., \& Hisrich, R. D. (1995). The venture capitalist: A relationship investor. California Management Review, 37(2): 101-113.

Freidson, E. (1986). Professional powers: A study of the institutionalization of formal knowledge. Chicago: University of Chicago Press.

Glaser, B., \& Strauss, A. (1967). The discovery of grounded theory. New York: Aldine de Gruyter.

Goa, G., Ting-Toomey, S., \& Gudykunst, W. (1996). Chinese communication processes. In M. Bond (Ed.), The handbook of Chinese psychology (pp. 135-158). Oxford: Oxford University Press.

Gorman, M., \& Sahlman, W. A. (1989). What do venture capitalists do? Journal of Business Venturing, 4: 231-248.

Great expectations. (1998, June). Asia Pacific Private Equity Bulletin: 1-4.

Guide to Venture Capital in Asia. (1998). The Asian Venture Capital Journal.

Guide to Venture Capital in Asia. (2000). The Asian Venture Capital Journal.

Gupta, U. (Ed.). (2000). Done deals: Venture capitalists tell their stories. Boston: Harvard Business School Press.

Hofstede, G., \& Bond, M. H. (1988). Confucius and economic growth: New trends in cultural consequences. Organizational Dynamics, 16(4): 4-21.

Jayasankaran, S. (2000, November 2). Revolt of the small investors. Far Eastern Economic Review, 2: 60-61.

Jeng, L. A., \& Wells, P. C. (2000). The determinants of venture capital funding: Evidence across countries. Journal of Corporate Finance, 6(3): 241-289.

Jepperson, R. (1991). Institutions, institutional effects, and institutionalism. In W. W. Powell \& P. J. DiMaggio (Eds.), The new institutionalism in organizational analysis (pp. 143163). Chicago: University of Chicago Press. 
Kao, J. (1993, March-April). The worldwide web of Chinese business. Harvard Business Review: 24-36.

Khanna, T., \& Palepu, K. (1999). The right way to restructure conglomerates in emerging markets. Harvard Business Review, 77(4): 125-134.

Kostova, T. (1997, August 3-6). Country institutional profiles: Concepts and measurement. Paper presented at the Academy of Management Annual Meeting, Boston, MA.

Lau, C. M., Tse, D. K., \& Zhou, N. (2002). Institutional forces and organizational culture in China: Effects on change schemas, firm commitment and job satisfaction. Journal of International Business Studies, 33: 533-550.

Lee, T. W. (1999). Using qualitative methods in organizational research. Newbury Park, CA: Sage.

Lincoln, Y. S., \& Guba, G. G. (1985). Naturalistic inquiry. Newbury Park, CA: Sage.

Low, C. K. (Ed.). (2000). Financial markets in Hong Kong. New York: Springer.

Low, C. K. (Ed.). (2002). Corporate governance: An Asia-Pacific critique. Hong Kong: Sweet \& Maxwell Asia.
Lowe, S. (1998). Culture and network institutions in Hong Kong: A hierarchy of perspectives. A response to Wilkinson. 'Culture, institutions and business in East Asia'. Organization Studies, 19: 321-343.

Lubman, S. B. (1999). Bird in a cage: Legal reform in China after Mao. Stanford, CA: Stanford University Press.

MacMillian, I. C., Kulow, D. M., \& Khoylian, R. (1988). Venture capitalist involvement in their investments: Extent and performance. Journal of Business Venturing, 4: 4-47.

McGrath, R. G. (1997). A real options logic for initiating technology positioning investments. The Academy of Management Review, 22: 974-996.

Mezias, M. S. (1990). An institutional model of organizational practice: Financial reporting at the Fortune 200. Administrative Science Quarterly, 35: 431-457.

North, D. (1990). Institutions, institutional change and economic performance. Cambridge: Cambridge University Press.

Orru, M., Biggart, N. W., \& Hamilton, G. G. (1997). The economic organization of East Asian capitalism. Newbury Park, CA: Sage.

Peng, M. W. (2000). Business strategies in transition economies. Newbury Park, CA: Sage.

Peng, M. W. (2002, August 12-14). Board composition and firm performance during institutional transitions. Paper Presented at the Academy of Management Annual Meeting, Denver, CO, U.S.A.

Peng, M. W. (2003). Institutional transitions and strategic choices. Academy of Management Review.

Peng, M. W., \& Heath, P. S. (1996). The growth of the firm in planned economies in transition: Institutions, organizations, and strategic choice. Academy of Management Review, 21(2): 492-528.

Peng, M. W., Luo, Y., \& Sun, L. (1999). Firm growth via mergers and acquisitions in China. In L. Kelley \& Y. Luo (Eds.), China 2000: Emerging business issues (pp. 73-100). Newbury Park, CA: Sage.

Phan, P. (2000). Taking back the boardroom. Singapore: McGrawHill.
Pratt's guide to venture capital sources. (2000). New York: Venture Economic.

1380

Rohwer, J. (2001). Remade in America: How Asia will change because America boomed. Singapore: Wiley.

Rosenstein, J. (1988). The board and strategy: Venture capital and high technology. Journal of Business Venturing, 3: 159-170.

Sahlman, W. A. (1988, Summer). Aspects of financial contracting in venture capital. Journal of Applied Corporate Finance, 1: 23-36.

Sapienza, H. (1992). When do venture capitalists add value? Journal of Business Venturing, 7: 9-27.

Sapienza, H., \& Gupta, A. K. (1994). Impact of agency risks and task uncertainty on venture capitalist: CEO interactions. Academy of Management Journal, 37: 1618-1632.

Sapienza, H., Manigart, S., \& Vermeir, W. (1996). Venture capitalist governance and value added in four countries. Journal of Business Venturing, 11: 439-469.

Saxenian, A. L. (1994). Regional advantage: Culture and competition in Silicon Valley and Route 128. Cambridge, MA: Harvard University Press.

Scott, W. R. (1995). Institutions and organizations. Newbury Park, CA: Sage.

Scott, W. R. (2002). The Changing world of Chinese enterprise: An institutional perspective. In A. S. Tsui \& C. M. Lau (Eds.), The management of enterprises in the People's Republic of China. London: Kluwer Academic Publishers.

Standifird, S. S., \& Marshall, S. R. (2000). The transaction cost advantage of guanxi-based business practices. Journal of World Business, 35(1): 21-42.

Strauss, A., \& Corbin, J. (1990). Basics of qualitative research: Grounded theory procedures and techniques. Newbury Park: Sage.

The Economist. (2000, April 29). Asian capitalism: The end of tycoons. The Economist: 67-69.

Timmons, J. A. (1999). New venture creation: Entrepreneurship for the 21st century (5th ed.). Singapore: McGraw-Hill.

Tsang, E., \& Walls, W. K. (1998). Can Guanxi be a source of competitive advantage for doing business in China. Academy of Management Executive, 12(2): 64-73.

Tsui, A. S., \& Lau, C. M. (2002). Research on the management of enterprises in the People's Republic of China: Current status and future directions. In A. S. Tsui \& C. M. Lau (Eds.), Management of enterprises in the People's Republic of China (pp. 1-27). London: Kluwer Academic Publishers.

Walsh, J. P., \& Kosnik, R. D. (1993). Corporate raiders and their disciplinary role in the market for corporate control. Academy of Management Journal, 36: 671-700.

Wang, C. K., \& Sim, V. Y. L. (2001). Exit strategies of venture capital-backed companies in Singapore. Venture Capital, 3(4): 337-358.

Webb-site.com. (1999, April 20). Hong Kong's not so independent directors (http://www.webb-site.com/articles/INED.htm).

Weidenbaum, M. (1996). The Chinese family enterprise. California Management Review, 38(4): 141-156.

Wright, M., Thompson, S., \& Robbie, K. (1992). Venture capital and management-led leveraged buy-outs: A European perspective. Journal of Business Venturing, 7(1): 47-71.
1382

1384

1386

1387

1389

1391

1392

1394

1395

1397

1398

1400

1402

1403

1404

1406

1407

1409

1410

1412

1414

1416

1417

1419

1420

1421

1422

1424

1425

1427

1428

1430

1432

1434

1435 
Xin, K. R., \& Pearce, J. L. (1996). Guanxi: Connections as substitutes for formal institutional support. Academy of Management Journal, 39(6): 1641-1658.

Yeung, I. Y. M., \& Tung, R. L. (1996). Achieving business success in Confucian societies: The importance of guanxi (connections). Organizational Dynamics, 25(2): 54-65.

Young, M. N., Ahlstrom, D., Bruton, G. D., \& Chan, E. S. (2001). The resource dependence, service and control functions of boards of directors in Hong Kong and Taiwanese firms. Asia Pacific Journal of Management, 18(3).

Zhuang, J. (1999). Corporate governance in East Asia and some policy implications (EDRC Briefing Notes Number 14). Economics and Development Resource Center, Asian Development Bank.

Zider, B. (1998). How venture capital works. Harvard Business Review, 76: 131-139. 